THE CRITICS DEBATE

General Editor: Michael Scott 
The Critics Debate

General Editor: Michael Scott

Published titles:

Sons and Lovers Geoffrey Harvey

Bleak House Jeremy Hawthorn

The Canterbury Tales Alcuin Blamires

Tess of the d'Urbervilles Terence Wright

Hamlet Michael Hattaway

The Waste Land and Ash Wednesday

Arnold P. Hinchliffe

Paradise Lost Margarita Stocker

King Lear Ann Thompson

Othello Peter Davison

Gulliver's Travels Brian Tippett 


\title{
THE WINTER'S TALE
}

\author{
Bill Overton
}

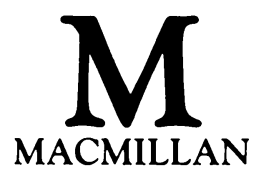




\section{(C) Bill Overton 1989}

Softcover reprint of the hardcover 1st edition 1989 978-0-333-44060-5

All rights reserved. No reproduction, copy or transmission of this publication may be made without written permission.

No paragraph of this publication may be reproduced, copied or transmitted save with written permission or in accordance with the provision of the Copyright Act 1956 (as amended), or under the terms of any licence permitting limited copying issued by the Copyright Licensing Agency, 33-4 Alfred Place, London WC1E 7DP.

Any person who does any unauthorised act in relation to this publication may be liable to criminal prosecution and civil claims for damages.

First published 1989

Published by

MACMILLAN EDUCATION LTD

Houndmills, Basingstoke, Hampshire RG21 2XS

and London

Companies and representatives

throughout the world

British Library Cataloguing in Publication Data

Overton, Bill

The Winter's Tale - (The Critics debate).

1. Drama in English. Shakespeare, William, 1564-1616. Winter's Tale.

I. Title II. Shakespeare, William 15641616. Winter's Tale. III. Series

$822^{\prime} .3^{\prime} 3$

ISBN 978-0-333-44061-2 ISBN 978-1-349-20036-8 (eBook)

DOI 10.1007/978-1-349-20036-8 
Contents

General Editor's Preface

Acknowledgements

A Note on Text and References

Introduction

Part One: Survey

1 Contexts

2 Evaluation

3 Imagery, symbolism, myth

4 Allegory and theme

5 Genre and convention

6 Structure and source

36

7 Marxism

41

8 Psychoanalysis

44

9 Feminism

46

10 Performance

Part Two: Appraisal

Introduction

11 Entertainment

12 Power, place, patriarchy

58

13 Theatricality

64

14 Autolycus

70

15 Restoring women

75

16 The final scene

82

References and Further Reading 86 Index 


\section{$\overline{\text { General Editor's }}$ Preface}

OVER THE last few years the practice of literary criticism has become hotly debated. Methods developed earlier in the century and before have been attacked and the word 'crisis' has been drawn upon to describe the present condition of English Studies. That such a debate is taking place is a sign of the subject discipline's health. Some would hold that the situation necessitates a radical alternative approach which naturally implies a 'crisis situation'. Others would respond that to employ such terms is to precipitate or construct a false position. The debate continues but it is not the first. 'New Criticism' acquired its title because it attempted something fresh, calling into question certain practices of the past. Yet the practices it attacked were not entirely lost or negated by the new critics. One factor becomes clear: English Studies is a pluralistic discipline.

What are students coming to advanced work in English for the first time to make of all this debate and controversy? They are in danger of being overwhelmed by the cross-currents of critical approaches as they take up their study of literature. The purpose of this series is to help delineate various critical approaches to specific literary texts. Its authors are from a variety of critical schools and have approached their task in a flexible manner. Their aim is to help the reader come to terms with the variety of criticism and to introduce him or her to further reading on the subject and to a fuller evaluation of a particular text by illustrating the way it has been approached in a number of contexts. In the first part of the book a critical survey is given of some of the major ways the text has been appraised. This is done sometimes in a thematic manner, sometimes according to various 'schools' or 'approaches'. In the second part the authors provide their own appraisals of the text from their stated critical standpoint, allowing the reader the knowledge of their own particular approaches from which their views may in turn be evaluated. The series therein hopes to introduce and to elucidate criticism of authors and texts being studied and to encourage participation as the critics debate. 


\section{Acknowledgements}

I WANT to thank the staff of Loughborough University Library for their help, especially the Inter-Library Loan Department; and also the Shakespeare Centre at Stratford-upon-Avon for allowing me access to books and archives.

Among individuals I am especially grateful to John Lucas for the stimulus of his essay on The Winter's Tale and for subsequent talk; to Michael Scott, General Editor of the series; and to Jim Friedman, David Fussell, Robin Hamilton and my wife Susan. All of these helped improve the book by reading and commenting on it in draft. Its remaining shortcomings are mine.

Bill Overton 


\section{A Note on Text and References}

ALL quotations from The Winter's Tale are from the New Penguin Shakespeare edition by Ernest Schanzer (1969). Quotations from other plays by Shakespeare are from The Complete Works edited by Peter Alexander (1951).

References to works of criticism are identified by the name of the author and the date of publication. Page numbers are given in brackets after quotations. Where no numbers appear the reference is the one given immediately before or after. Several of the critical works discussed have been reprinted in full or part in Kenneth Muir's Casebook on The Winter's Tale (London, 1968). References are made to this whenever possible, and are indicated by the name Casebook and the page number(s).

Full bibliographical details are provided in the References section at the end. For convenience in referring to works discussed in Part One, this is divided according to each of its ten sections, with added to most of these a number of titles for further reading. All other works referred to are included in a general section at the end. 